\title{
Filosopi Kearifan Lokal Tri Hita Karana Dalam Menjaga Kelangsungan Kelompok Wanita Tani “Jempiring" Kabupaten Badung
}

\author{
I Gusti Ayu Diah Yuniti', Anak Agung Ayu Rai Wahyuni², Anak Agung Rai Tirtawati ${ }^{3}$, \\ Ni Wayan Suryathi ${ }^{4}$, I Gde Agoes Caskara Surya Putra ${ }^{5}$ \\ ${ }^{15}$ Universitas Mahasaraswati Denpasar \\ ${ }^{2}$ Universitas Udayana Denpasar \\ ${ }^{3}$ Universitas Dwijrendra Denpasar \\ ${ }^{4}$ Universitas Pendidikan Nasional \\ 1diahyuniti123@unmas.ac.id, 2ajungayu29@gmail.com, ${ }^{3}$ aa.raitirtawati57@ gmail.com, \\ ${ }^{4}$ wayansuryathi@undiknas.ac.id, 5 ajuschaskara@gmail.com
}

\begin{abstract}
This study aims to analyze the sustainability of the "Jempiring" Women Farmers Group, Badung Regency through the implementation of tri hita karana local wisdom. This study uses secondary data sources. The types of data include qualitative data. The data analysis technique is using qualitative analysis. Based on the results of the discussion, it can be concluded that the sustainability of the Women Farmers Group (KWT) "Jempiring" in Badung Regency is still running. This is due to the belief of the group members to continue to implement the local wisdom of tri hita karana in terms of parayangan, pawongan and palemahan. The implementation of various rituals (religious ceremonies) as a form of devotion to Ida Hang Hyang Widhi Waca, for the yadnya human ceremony, as well as for the implementation of the nyomia butha kala ceremony, continues.
\end{abstract}

Keywords: Continuation of The “Jempiring” Women Farmers Group; Tri Hita Karana

\begin{abstract}
Abstrak
Tujuan penelitian ini adalah untuk menganalisis kelangsungan Kelompok Wanita Tani "Jempiring", Kabupaten Badung melalui implementasi kearifan lokal tri hita karana. Sumber data yang digunakan dalam penelitian ini adalah data sekunder. Jenis datanya meliputi data kualitatif. Teknik analisis data adalah menggunakan analisis kualitatif. Berdasarkan hasil pembahasan dapat disimpulkan bahwa kelangsungan Kelompok Wanita Tani (KWT) "Jempiring" Kabupaten Badung hingga kini usahanya masih terus berjalan. Hal ini disebabkan karena keyakinan anggota kelompok dalam mengimplementasikan kearifan lokal tri hita karana baik dari sisi parahyangan, pawongan dan palemahan tidak pernah putus. Pelaksanaan berbagai ritual (upacara keagamaan) sebagai wujud bhakti kepada Ida Hang Hyang Widhi Waca, untuk upacara manusia yadnya, maupun untuk pelaksanaan upacara nyomia butha kala, tetap berlangsung.
\end{abstract}

Kata Kunci: Kelangsungan Kelompok Wanita Tani “Jempiring”; Tri Hita Karana

\section{Pendahuluan}

Dalam peradabannya masyarakat adat di Bali dengan spririt agama Hindu, sejak jaman dahulu dikenal sebagai masyarakat sosial, memiliki banyak konsep dalam menjalani kehidupannya (Subagia et al., 2016). Beberapa konsep yang dimiliki dan sangat dikenal oleh masyarakat Bali yakni rwa bhinneda, catur loka pala, sadwinayaka, 
asta bhuwana, triloka, tri hita karana, tri mandala, luan-teben, dan lain-lain; berbentuk simbol-simbol agama, seperti Pura (temple), Suastika, Ongkara, Pratima, Arca-arca, dan lain-lain; simbol alam, seperti gunung, laut, hutan, sungai, danau, bulan, bintang, matahari dan lain-lain; dalam bentuk sikap dan tingkah laku dalam kehidupan seharihari, seperti keyakinan dengan adanya hukum karma, doa sebelum dan sedang melakukan kegiatan, gotongroyong, menghargai sesama, dan lain-lainnya. Keberadaan semua konsep, simbolsimbol keagamaan, sikap dan perilaku kehidupan sosial, dan lain-lain diyakini hidup berkelanjutan sepanjang adat-istiadat dan tradisi budaya masih membingkai kehidupan umat Hindu di Bali. Berbicara tentang konsep harmonisasi, bahwa salah satu di antara konsep Hindu yang paling dikenal adalah konsep tri hita karana (Raka et al., 2017).

Tri hita karana, secara etimologi terbentuk dari kata : tri yang berarti tiga, hita berarti kebahagiaan, dan karana yang berarti sebab atau yang menyebabkan. Jadi tri hita karana dimaknai sebagai tiga hubungan harmonis yang menyebabkan kebahagian (Subagia et al., 2016). Tri hita karana berarti tiga penyebab kebahagiaan. Ketiga unsur dimaksud adalah parhyangan (Tuhan), pawongan (manusia), dan palemahan (alam). Ketiga unsur yang menjadi bagian dari konsep ini keberadaannya sangat universal sehingga mudah dikenal dan dipahami. Kebahagiaan dapat dicapai dengan menciptakan dan memelihara hubungan harmonis di antara ketiga unsur tersebut. Dalam hal ini adalah peran manusia (orang) Bali sebagai subjek untuk membangun dan menata hubungan harmoni antara manusia dengan Tuhan; manusia dengan manusia; dan manusia dengan alam (Raka et al., 2017).

Konsep harmonisasi hubungan yang selalu dijaga oleh masyarakat Hindu di Bali dikenal sebagai salah satu jenis kearifan lokal Bali (Karyati dan Suryathi, 2018). Tri hita karana (THK) sebagai salah satu kearifan lokal masyarakat Bali, warisan nenek moyang (para leluhur) yang berbasis Hinduitis sudah menjadi pegangan dan pandangan hidup masyarakat Bali sejak dulu kala. Data sejarah menunjukkan: kebudayaan pertanian sudah dikenal di Bali pada tahun caka 522 (Goris, ?), diperkuat oleh Prasasti Sukawana (caka 800) dan Prasasti Trunyan (caka 813), pada saat itu subak yang berfalsafah THK sudah dikenal di Bali. Aspek filosofis THK bersumber pada 4 (empat) pemikiran filsafat, yaitu: aspek Teosentris, Kosmosentris, Antroposentris, dan Logosentris. Teosentris merupakan teori pemikiran filsafat bahwa segala sesuatu bersumber dari Tuhan. Tuhan sebagai pencipta alam semesta beserta isinya. Antroposentris merupakan teori pemikiran filsafat bahwa manusia sebagai titik pusatnya, karena manusia lengkap memiliki tri pramana (sabda, bayu, dan idep) yang merupakan kelebihan dari makhluk hidup lainnya, yakni memiliki kemampuan berpikir. Pada teori pemikiran filsafat Kosmosentris bahwa alamlah yang menjadi titik pusat segalanya, sedangkan Logosentris merupakan teori pemikiran filsafat bahwa istilah atau pernyataan/ungkapan yang menjadi sumbernya. Dalam hal ini Logosentris menjiwai istilah atau kata harmoni dalam THK yang dijadikan interpretasi filsafat hidup orang Bali yang senantiasa berproses, berubah, inovatif, dan konstruktif. Jadi keempat fase pemikiran tersebut diramu menjadi filsafat hidup THK sebagai suatu konsep harmoni, yang menyangkut keseimbangan hubungan manusia dengan Tuhan (Parhyangan), keseimbbangan hubungan antar sesama manusia (Pawongan), dan keseimbangan hubungan antara manusia dengan alam lingkungannya (Palemahan). Dalam kehidupan sehari-hari, bahwa dalam konsep ini manusialah menjadi subjek dalam implementasi THK (Agung \& Sugianthara, 2015).

Dalam filosofi tri hita karana (THK) bahwa untuk menuju hidup yang sejahtera, lebih ditekankan pada manusia untuk menjaga keserasian atau keharmonisan. Keharmonisan antara manusia dengan penciptanya, yakni Tuhan yang Maha Esa yang disebut (parhyangan), manusia dengan alam atau lingkungannya yang disebut (palemahan) dan manusia dengan sesamanya yang disebut (pawongan) (Bagiada \& 
Darmayasa, 2015) dalam (Wulandari, 2020). Dalam mengimplementasikan konsep tri hita karana sangat ditekankan bahwa ketiga unsurnya harus diaplikasikan secara utuh dan terpadu. Unsur parahyangan, pawongan, dan palemahan tidak ada yang menduduki porsi yang istimewa. Ketiganya senantiasa harus seimbang dalam pemikiran, dalam ucapan dan seimbang pula dalam segala tindakan. Sebagai konsep keharmonisan Hindu, tri hita karana telah memberikan apresiasi yang luar biasa dari berbagai masyarakat dunia (Subagia et al., 2016)

Memasuki era globalisasi dan era digitalisasi, kesadaran Kelompok Wanita Tani (KWT) Unit Pelayanan Pengembangan dan Pengolahan Hasil Pertanian (UP3HP) yang selanjutnya disebut LWT "Jempiring" Kabupaten Badung yang dalam kesehariannya bergerak dalam bidang pembuatan dan penjualan jaje begina (jajan untuk upacara keagamaan Hindu di Bali) dan beraneka jajan lainnya (jajan basah) masih tetap menyadari pentingnya untuk mengimplementasikan kearifan lokal tri hita karana. Hal ini karena anggota kelompok sangat meyakini bahwa dengan kekuatan menjaga hubungan harmonis, maka usaha yang dijalankan akan memberikan hasil sesuai dengan karmanya masingmasing. Ketekunan dalam menjalankan usaha karena anggota kelompok memiliki kesadaran untuk membantu mencukupi kebutuhan hidup keluarga. Dengan berbagai masalah dan kendala yang dihadapi, baik secara internal maupun eksternal, itu semua merupakan tantangan yang perlu diatasi melalui berbagai cara, seperti: pertemuan kelompok harus tetap dilakukan secara rutin, peningkatan efektivitas penyuluhan dan pelatihan oleh pemerintah agar terus dilakukan, bantuan modal dan peralatan juga tetap diharapkan oleh karelompok. Hal ini akan menjadi motivasi dan merupakan insentif bagi keberpihakan kelompok wanita tani yang ada selama ini (Ervinawati et al., 2015).

Berdasarkan hasil observasi pada Kelompok Wanita Tani "Jempiring” Kabupaten Badung di lapangan permasalahan penurunan omzet penjualan yang dihadapi oleh anggota kelompok selama masa pandemic covid-19 ini tidak menurunkan semangat anggota kelompok dalam mengimplementasikan kearifan lokal tri hita karana, sehingga penurunan keuntungan yang diperoleh dianggap sebagai bagian yang harus diterima dalam menjaga kehidupan yang harmonis di Bali, karena memiliki kepercayaan akan adanya hukum karma phala.

\section{Metode}

Penelitian ini dilakukan pada Kelompok Wanita Tani "Jempiring” Kabupaten Badung. Sumber data yang digunakan terdiri dari data primer dan sekunder, jenis data pada penelitian ini adalah data kualitatif. Cara pengumpulan data melalui studi dokumentasi, observasi dan wawancara. Studi dokumentasi yakni cara perolehan data dengan mempelajari berbagai dokumen melalui jurnal dan buku-buku terkait dengan implementasi tri hita karana. Observasi dilakukan dengan mengadakan pengamatan ke lokasi Kelompok Wanita Tani "Jempiring" berusaha yakni di Banjar Tengah Desa Blahkiuh, Kecamatan Abiansemal, Kabupaten Badung dengan melihat, mempelajari dan mencatat sekaligus melakukan wawancara dengan anggota kelompok terkait dengan implementasi kearifan lokal tri hita karana. Teknik analisis data menggunakan analisis analisis kualitatif. Menurut Flick (2007) dalam (Junaid, 2018) bahwa penelitian kualitatif adalah penelitian yang diperuntukkan untuk memahami, menguraikan, dan bahkan menjelaskan fenomena sosial yang ada dengan cara-cara sebagai berikut: 1) menganalisis pengalaman dari individu-individu atau kelompok berkaitan dengan sejarah hidup seseorang, pengetahuannya ataupun cerita yang berkaitan dengan hidupnya. 2) menganalisis interaksi dan komunikasi setiap individu atau kelompok. 3) menganalisis dokumen-dokumen (misalnya teks, gambar, film atau musik). Penelitian kualitatif ini lebih menguraikan realita ataupun fenomena yang ada di masyarakat dari sudut pandang 
informan atau orang yang berpartisipasi yang diwawancarai (termasuk wawancara mendalam). Sesungguhnya, realitas sosial yang ada di masyarakat memiliki makna sehingga penelitian kualitatif bertujuan untuk memahami apa yang terjadi baik dilihat dari prosesnya maupun pola-pola makna yang terjadi di masyarakat. Penelitian kualitatif senantiasa melihat realitas sosial dalam konteks apa yang terjadi dan mengapa sesuatu terjadi di masyarakat. Selanjutnya, penelitian kualitatif memberikan solusi, pendekatan ataupun strategi yang dapat ditempuh berdasarkan fenomena yang sedang diteliti (Junaid, 2018).

\section{Pembahasan}

\section{Keberadaan Kelompok Wanita Tani}

Kelompok Wanita Tani (KWT) merupakan suatu wadah yang memberikan kesempatan bagi kaum perempuan untuk ikut andil dalam memajukan sektor pertanian. Kelompok Wanita Tani digunakan sebagai sarana untuk kelancaran kegiatan pembinaan kepada Kelompok Wanita Tani dalam meningkatan kualitas sumber daya wanita. Salah satu kegiatan yang bisa mengaktualisasi kaum perempuan yaitu dengan mengikuti organisasi kelompok wanita (Purnamasari, 2014). Pembentukan Kelompok Wanita Tani karena adanya masalah ekonomi keluarga yang belum mencukupi untuk memenuhi kebutuhan keluarga sehari-hari, sehingga wanita dituntut untuk terlibat dalam kegiatan kelompok dengan mengorbankan waktu, mencurahkan pikiran dan tenaganya. Dalam kegiatan usahanya peran wanita pada umumnya bekerja dalam beberapa aspek produksi (pengolahan dan pemasaran hasil pertanian) dan pasca panen. Dengan terbentuknya Kelompok Wanita Tani ini memunculkan konsep kemitraan wanita dan pria sehingga meningkatkan kualitas peranan wanita dalam berbagai aktivitas pembangunan (Ervinawati et al., 2015). KWT “Jempiring” Kabupaten Badung merupakan wadah yang dibentuk untuk memberikan kesempatan bagi perempuan di Banjar Tengah Desa Blahkiuh, Kecamatan Abiansemal, Kabupaten Badung untuk menyalurkan kemampuannya dalam mengolah dan pemasaran hasil pertanian.

\section{Implementasi Kearifan Lokal Tri Hita Karana KWT "Jempiring" Kabupaten Badung}

Komitmen pemerintah Kabupaten Badung terhadap pemberdayaan kaum perempuan di desa dilakukan dengan memberikan alokasi dana bantuan untuk Kelompok Wanita Tani (KWT) Unit Pelayanan Pengembangan dan Pengolahan Hasil Pertanian (UP3HP) sebesar Rp 25.000.000,00. Tujuan bantuan ini adalah untuk pemberdayaan perempuan, sehingga mampu membantu keuangan keluarga, dan pada akhirnya perempuan juga memiliki hak untuk mendapatkan kesejahteraan sosial. Sebagaimana yang dijelaskan dalam Undang Undang No 11 Tahun 2009 tentang kesejahteraan sosial pasal 1 bahwa kesejahteraan sosial adalah kondisi terpenuhinya kebutuhan material, spiritual dan sosial warga Negara agar dapat hidup layak dan mampu mengembangkan diri, sehingga dapat melaksanakan fungsi sosialnya (Indonesia, 2009).

Salah satu aktivitas yang dijalankan oleh KWT "Jempiring" Kabupaten Badung untuk meningkatkan kesejahteraan keluarganya adalah dengan melakukan pengolahan dan pemasaran hasil-hasil produk pertanian menjadi jaje begina, serta jajan lainnya (jajan basah). Dalam aktivitasnya anggota kelompok ini senantiasa mengedepankan hubungan harmonis agar usahanya bisa tetap bertahan atau berkesinambungan. Dalam mengimplementasi hubungan harmonis melalui kearifan lokal tri hita karana KWT "Jempiring" Kabupaten Badung melakukannya dengan memperhatikan ketiga unsur tri hita karana yakni dari unsur parhyangan yakni hubungan manusia dengan Tuhan Yang Maha Esa, hubungan manusia dengan sesamanya yang disebut pawongan dan hubungan manusia dengan alam atau lingkungannya yang disebut (palemahan). 
Berdasarkan hasil wawancara dengan ketua kelompok Ibu Ni Made Arsaniyati (umur 55 tahun) pada tanggal 10 Nopember 2021, pukul 15.30 bertempat di rumahnya di Banjar Tengah Desa Blahkiuh, Abiansemal Badung yang mewakili kelompok dalam memberikan data dan informasi terkait dengan implementasi kearifan lokal tri hita karana, menyatakan bahwa ketua kelompok mengenal kearifan lokal tri hita karana yakni sebagai hubungan harmonis dengan Ida Sang Hyang Widhi Waca, yang ditunjukkan dengan ketekunan dan keyakinanya mempersembahkan sesajen setiap hari, setiap lima belas hari sekali (Purnama, Tilem) serta setiap hari-hari besar agama Hindu di Bali (Galungan, Kuningan, Nyepi, dan lain-lainnya). Sebagaimana ditunjukkan pada salah satu kegiatan upacara keagamaan saat piodalan di Pura Melanting pada Gambar 1, Gambar 2 dan Gambar 3 berikut.

Gambar: 1

Persembahan di tempat berjualan jajan di Pasar

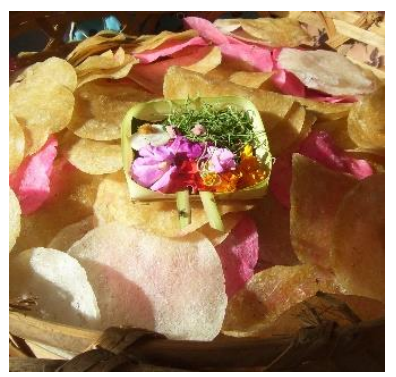

Sumber: Foto Pribadi (2021)
Gambar: 2

Persembahan di Pura Melanting

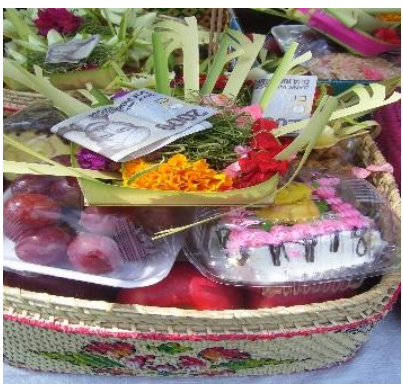

Gambar: 3

Persembahyangan Bersama di Pura Melanting

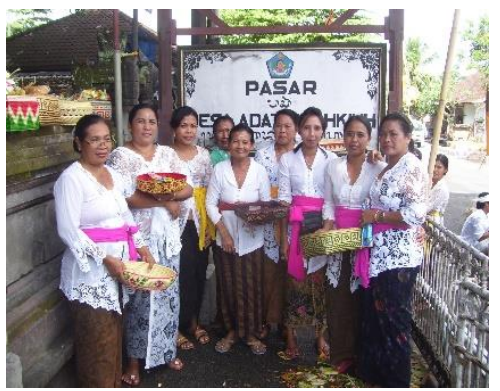

Unsur pawongan merupakan hubungan harmonis yang dijaga oleh anggota KWT "Jempiring" Kabupaten Badung terhadap sesama umat manusia, baik dalam lingkungan intern kelompok maupun dengan lingkungan eksternal anggota kelompok yang dilakukan setiap hari oleh anggota kelompok. Bersosialisasi dalam rapat bulanan salah satu bentuk dalam menjaga hubungan harmonis diantara sesama anggota kelopok, melakukan kunjungan (menyama braya) secara bergantian dalam setiap pelaksanaan upacara manusia yadnya yang ada di lingkungan anggota kelompok, maupun yang ada di lingungan Desa tempat dimana anggota kelompok tinggal. Serta kegiatan lainnya yang terkait dengan hubungan sesama manusia. Hubungan harmonis yang dijaga oleh anggota kelompok dapat ditunjukkan pada Gambar 4, Gambar 5, dan Gambar 6 berikut.

Gambar: 4

Hubungan anggota

kelompok dengan

Pelanggan di Pasar

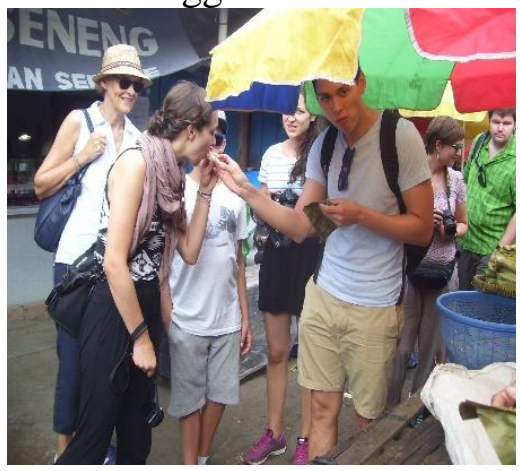

Sumber: Foto Pribadi (2021)
Gambar: 5

Ketua kelompok memimpin rapat bulanan

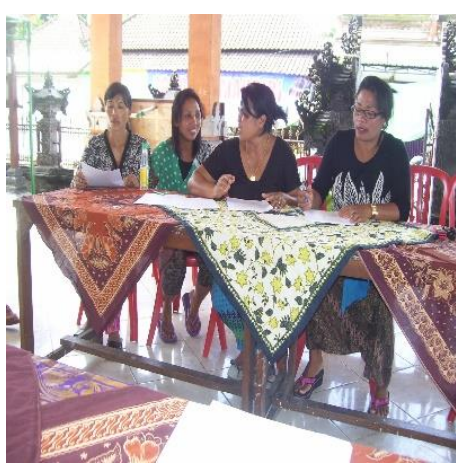

Gambar: 6

Hubungan anggota kelompok dengan pegawai BRI di Pasar

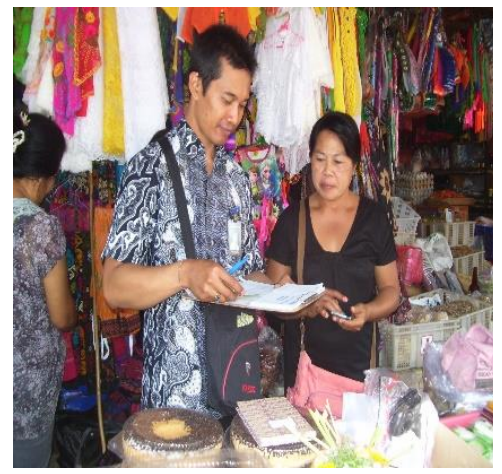


Implementasi hubungan harmonis dengan alam atau lingkungannya yang disebut palemahan. Anggota KWT "Jempiring" Kabupaten Badung dalam menjaga hubungan harmonis dengan lingkungannya yakni dengan melakukan persembahan kepada Ibu Pertiwi (mesegeh atau mecaru) sebagai ucapan terimakasih (Nyomia butha kala), serta menjaga tanaman yang digunakan dalam berbagai upacara keagamaan. Anggota kelompok yang berjualan di Pasar juga selalu menjaga lingkungan agar tetap bersih, dengan menyapu dan membersihkan lingkungan tiap berjualan. Menjaga keadaan jajan agar terlindung dari kotoran, dan tetap menjaga agar jajan bersih dan sehat, dengan penggunaan bahan-bahan alami dan sehat, sehingga bisa aman untuk digunakan dalam persembahan. Setaip hari raya tumpek anggota kelompok senantiasa taat dalam melakukan ritual baik untuk tanaman maupun untuk hewan peliharaan yang senantiasa tetap dijaga hingga kini. Berikut kegiatan yang tetap dijaga ditunjukkan pada Gambar 7, Gambar 8 dan Gambar 9 berikut.

Gambar: 7

Hubungan harmonis dengan Ibu Pertiwi

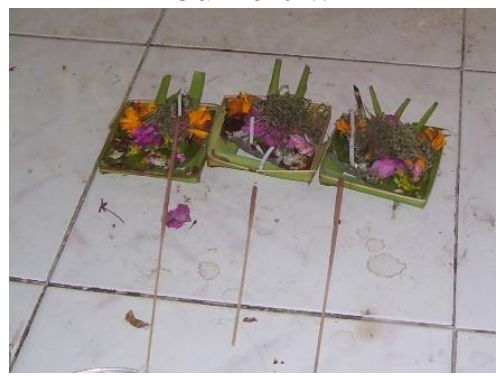

Gambar: 8 Menjaga Kelangsungan

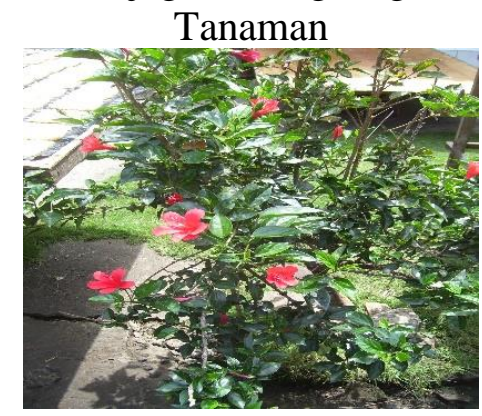

Gambar: 9 Hubungan harmonis dengan Mesegeh

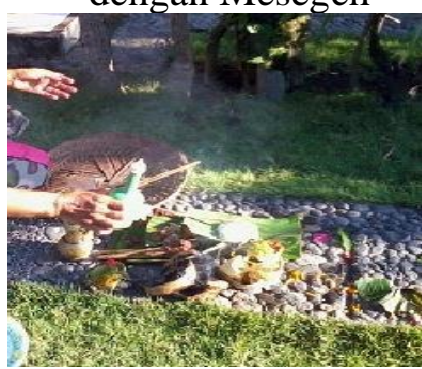

Sumber: Foto Pribadi (2021)

Kehidupan sehari-hari anggota KWT "Jempiring” Kabupaten Badung dalam pelaksanaan upacara/ritual senantiasa berpedoman pada warisan lelulur yang sudah diterima secara turun temurun dan sangat diyakini sebagai sumber kebahagiaan. Ritual memiliki nilai ketuhanan atau makna teologis (Donder, 2017). Makna teologis bersifat inflisit maupun ekspisit sebagaimana tersurat dalam teks pustaka suci Hindu. Makna atau hakikat teologis dari yadnya atau upacara ritual menurut Bhagavadgita III.9): "Yajnarthat karmano nyatro loko yam karma-bandhanah, tad-artham karma kaunteya mukta-sangah samacara". Yadnya berarti kurban suci yang dilaksanakan secara tulus ikhlas. Dalam perspektif religius, terutama dalam tradisi Hindu Bali, yadnya lebih diartikan sebagai ritual. Sloka Bhagavadgita III.9) di atas sebagai sumber teologis memberi informasi yang jelas tentang hakikat yadnya (kurban suci) yang dilaksanakan secara tulus ikhlas. Yadnya atau ritual merupakan sumber hukum karma (hukum sebab dan akibat) menjadi sumber aktivitas relegius, bahwa ritual oleh mayoritas umat Hindu di Bali disamakan artinya dengan banten yakni suatu kurban suci dalam bentuk sesajen yang terdiri dari berbagai macam bahan, baik yang terbuat dari bahan tumbuhan maupun hewan (Donder, 2017).

Filosopi tri hita karana bagi masyarakat Hindu sebagai sebuah tradisi diajarkan juga dalam Bhagawadgita yakni mengajarkan tentang sikap hidup yang seimbang antara memuja Tuhan, dengan mengabdi kepada sesama manusia serta mengembangkan kasih sayang pada alam lingkungannya. Adanya konsep tri hita karana yang menjiwai nafas kehidupan orang Bali (Hindu) menjadikan Bali harmonis secara makro kosmos maupun mikro kosmos (Purana, 2016). Perwujudan rasa bhaktinya kepada Tuhan, dengan Tuhan ada di dalam seluruh sarana banten, sangat sesuai dengan teologi Hindu yakni Teologi Panteis. Teologi ini menjelaskan bahwa seluruh partikel atom sekalipun menjadi tempat hunian Tuhan, karena Tuhan Maha Kuasa memiliki kemampuan untuk menjadikan diriNya sangat besar dan sekaligus juga sangat kecil atau sangat halus melebihi ukuran 
partikel elektron atom. Sifat Tuhan yang Panteis inilah kemudian tertuang dalam Veda sebagai ungkapan sarva khalv'idam Brahman yang artinya "seluruh alam semesta beserta isinya adalah wujud Tuhan itu sendiri. Karena Tuhan yang sifat-Nya panteistis meresapi seluruh alam semesta (Donder, 2017).

Pelaksanaan yadnya yang dilakukan oleh anggota KWT "Jempiring" Kabupaten Badung sebagai bentuk implementasi dari tri hita karana baik hubungannya dengan Ida Sang Hyang Widhi Waca, dengan sesama umat manusia, maupun dengan alam lingukungannya akan memerlukan sarana penunjang berupa artha. Konsep artha (dalam catur purusa artha) dan panca yadnya inilah akhirnya mendorong masyarakat Hindu di Bali umumnya dan anggota KWT pada khususnya untuk bekerja keras agar memperoleh pendapatan dalam memenuhi segala kebutuhannya. Dalam pelaksanakannya konsep artha tidak dapat terlepas dan haruslah berpedoman pada konsep dharma, kama, dan moksa (Riana, 2011). Untuk bisa memperoleh artha anggota KWT "Jempiring" Kabupaten Badung melakukannya dengan bekerja secara berkelompok agar dapat memenuhi kebutuhan hidupnya termasuk keperluan untuk ritual (upacara keagamaan). Menurut Gorda (1995) bahwa seseorang tidak akan mencapai kebahagiaan dengan diam atau tanpa bekerja. Dalam Sloka Bhagavadgita IV.12 dinyatakan bahwa, seseorang yang berharap suatu keberhasilan dari aktivitas kerjanya, maka ia harus ber-yadnya (melakukan kurban suci) kepada Tuhan di dunia ini, karena aktivitas kerja akan segera terwujud jika disertai dengan yadnya atau kurban suci, baik dalam bentuk material maupun dalam bentuk spiritual. Kurban suci dalam bentuk materi bisa berbentuk banten (canang) sedangkan kurban suci dalam bentuk spiritual bisa dalam bentuk doa atau meditasi. Sloka di atas memberikan petunjuk bahwa orang yang ingin hidup berhasil di dunia ini harus rajin "bekerja dan berdoa".

Sebagaimana penelitian yang dilakukan oleh Sukarsa bahwa sekitar 32\% dari pendapatan orang Hindu di Bali digunakan untuk konsumsi ritual agama dalam bentuk yadnya (Ramantha, 2010). Pelaksanaan yadnya biasanya dilakukan karena adanya kesadaran dari kalangan bisnis bahwa kegiatannya pada hakekatnya dikontrol oleh Tuhan Yang Maha Esa (Windia, W. dan Dewi, 2007). Pengeluaran untuk yadnya tersebut merupakan salah satu cermin pemahaman dan pelaksanaan terhadap nilai-nilai agama (Ramantha, 2010). Adanya pola konsumsi untuk ritual yang cukup tinggi telah mendorong perilaku masyarakat Hindu di Bali untuk bekerja keras agar dapat memenuhi kebutuhan hidupnya. Berdasarkan pemikiran (Berger, dan Luckmann, 1990), bahwa perilaku di kalangan anggota KWT Jempiring Kabupaten Badung dalam melaksanakan persembahan atau ritual mebanten itu merupakan kebiasaan (habit) yang sudah diterima secara turun temurun dari para leluhur. Melalui kegiatan mebanten anggota KWT Jempiring Kabupaten Badung yakin akan diberikan keselamatan dalam usahanya, sehingga melalui usahanya yang dilakukan dengan berkelompok akan dapat memperoleh keuntungan, akan dapat memperoleh bantuan dari Pemerintah Kabupaten Badung, yang pada akhirnya bahwa keuntungan tersebut dapat meningkatkan kesejahtraan anggota keluarganya (keluarga jagadita). Dengan dimikian kelangsungan hidup anggota KWT Jempiring Kabupaten Badung akan tetap dapat terjaga.

Semangat kerja KWT Jempiring Kabupaten Badung, sejalan dengan spirit kapitalisme modern (Weber, 2006) bahwa keberhasilan ekonomi tidak hanya karena faktor ekonomi, tetapi karena didorong oleh sistem moral, adanya anthusiasme, etos kerja, dan efisiensi maksimal yang menuntut pengabdian manusia kepada panggilan kerja. Kerja merupakan suatu tujuan pribadi dari setiap orang, kerja sebagai sesuatu yang melekat di dalam eksistensi hidup manusia. Pandangan anggota KWT Jempiring Kabupaten Badung terhadap kerja, bahwa dengan semangat kerja yang tinggi, maka akan dapat meningkatkan kesejahtraan seluruh keluarganya. Dengan bekerja keras, bekerja cerdas, maka anggota 
kelompok akan memperoleh hasil, tanpa meninggalkan implementasi kearifan lokal tri hita karana tersebut. Semangat ini juga sesuai dengan ajaran Hindu yang dikutif dari Atharveveda, XX.18.3 yang menyatakan: "Tuhan hanya menyayangi orang yang bekerja keras dan tidak menyukai orang yang malas bekerja. Orang yang senantiasa bekerja berdasarkan kesadarannya memperoleh kebahagiaan tertinggi" (Suryathi, 2019). Kutipan di atas jika dikaitkan dengan pendapat (Weber, 2006) yang menyatakan bahwa hanya mereka yang memiliki vocational ethics akan dengan baik meningkatkan prestasi hidupnya. Artinya bahwa hanya manusia yang mau bekerja keras akan dapat memperoleh hasil, sehingga mampu meningkatkan taraf hidupnya.

Dalam agama Protestan yang dikembangkan oleh Calvin bahwa etika protestan sebagai sebuah konsep dan teori dalam teologi, sosiologi, ekonomi, dan sejarah yang mempersoalkan masalah manusia yang dibentuk oleh nilai-nilai budaya di sekitarnya, khususnya nilai agama. Bahwa seorang manusia sudah ditakdirkan sebelumnya sebelum masuk ke surga atau ke neraka ditentukan berhasil atau tidak dalam pekerjaannya di dunia (Weber, 2006). Dalam kaitannya dengan kerja sebagai persembahan (yadnya) harus dilaksanakan secara benar seperti terungkap dalam Bhagavadgita, VII.13: bahwa yadnya yang dilakukan tanpa aturan, dimana makanan tidak dihidangkan tanpa mantra, dan sedekah, serta tanpa keyakinan dinamakan tamas. Berdasarkan kutipan sloka Bhagavadgita, VII.13 dinyatakan bahwa persembahan (yadnya) harus memenuhi syarat: (1) mengikuti petunjuk pustaka suci Veda; (2) melaksanakan kerja yang produktif; (3) memahami hubungan yang nyata antara kerja dengan kehidupan, baik dalam rangka mencapai kebahagiaan yang bersifat duniawi, maupun kebahagiaan abadi di surga; (4) memiliki rasa berkorban materiil (dana-punia) kepada pendeta, dan sesama manusia serta alam, tanpa imbalan jasa; (5) melalui kerja dan pelayanan yang baik, kebahagiaan yang bersifat duniawi maupun surgawi dapat diwujudkan (Gorda, 2003). Prinsip yang telah dilaksanakan oleh orang-orang Jepang yang menyadari bahwa dunia fisik dan dunia spiritual memiliki kedudukan yang sama-sama penting, dan upaya untuk memisahkan keduanya atau membiarkan keduannya dalam keadaan tidak seimbang akan membuahkan suatu ketidakharmonisan yang berpotensi menimbulkan kerusakan (Boye, 2009).

\section{Kesimpulan}

Berdasarkan hasil pembahasan mengenai filosopi kearifan lokal tri hita karana dalam menjaga kelangsungan Kelompok Wanita Tani (KWT) "Jempiring" Kabupaten Badung dapat disimpulkan bahwa hingga kini seluruh anggota kelompok tetap secara rutin melaksanakan berbagai ritual (upacara keagamaan) sebagai wujud bhakti kepada Ida Hang Hyang Widhi Waca, melaksanakan ritual untuk upacara manusia yadnya, melaksanakan upacara tumpek baik ritual untuk tanaman maupun hewan. Ucapan terimakasih melalui persembahan dan persembahyangan kepada Ida Sang Hyang Widhi Waca yang telah memberikan perlindungan terhadap kelangsungan usaha kelompok, yang semua merupakan bentuk wujud implementasi tri hita karana dari sisi parahyangan. Kerjasama kelompok hingga kini masih terjalin dengan baik, sehingga kelangsungan kelompok tetap terjaga adalah implementasi dari sisi pawongan. Kesadaran anggota kelompok dalam menjaga kebersihan lingkungan di rumah, di pasar, serta menjaga kebersihan dan kesehatan jajan yang dibuat untuk dijual adalah implementasi dari kearifan lokal tri hita karana dari sisi palemahan.

\section{Daftar Pustaka}

Agung, A., \& Sugianthara, G. (2015). Implementasi Tri Hita Karana Dalam Pengelolaan Lingkungan Hidup Di Bali Dalam Menjaga Eksistensi Bali Sebagai Pulau Taman. Prodi. Arsitektur Pertamanan Fak. Pertanian Universitas Udayana Denpasar. 
Berger, P. dan L. T. (1990). Tafsir Sosial Atas Kenyataan: Risalah Tentang Sosiologi Pengetahuan (diterjemahkan dari buku asli the Social Construction of Reality oleh Hasan Basari). Jakarta: LP3ES., 23(2), 117-120.

Boye, D. M. (Terjemahan). (2009). Misteri Kode Samurai Jepang. Yogyakarta: Penerbit Gara Ilmu Yogyakarta., 3(3), 103-112.

Donder, I. K. (2017). Unsur-unsur Sain dan Teknologi dalam Ritual Hindu. Surabaya: Wordd Hindu Parisad Dan Paramita, 7(1), 1. https://doi.org/10.23887/vjra.v7i1.20737.

Ervinawati, V., Fatmawati, \& L, E. I. (2015). Peranan Kelompok Wanita Tani Perdesaan Dalam Menunjang Pendapatan Keluarga (Di Dusun Beringin Desa Sungai Rengas Kecamatan Sungai Kakap, Kabupaten Kubu Raya Provinsi Kalimantan Barat). Jurnal Tesis PMIS-UNTAN-PSS-2015, 39, 1-4.

Gorda, I. G. N. (2003). Membudayakan Kerja Berdasarkan Dharma. Singaraja: Pusat Kajian Hindu. Budaya dan Perilaku Organisasi. Sekolah Tinggi Ilmu Ekonomi Satya Dharma., 1(1), 1-14. https://doi.org/ 10.20885/ cantrik.vol1.iss1.art1.

Indonesia, P. R. (2009). Undang-Undang Republik Indonesia Nomor 11 Tahun 2009 Tentang Kesejahteraan Sosial. UU No. 11 Tahun 2009 Tentang Kesejahteraan Sosial [JDIH ...Https://Peraturan.Bpk.Go.Id, 0365.

Junaid, I. (2018). Analisis Data Kualitatif Dalam Penelitian Pariwisata. 10(01), 59-74. https://doi.org/10.31219/ osf.io/npvqu.

Karyati, I. N. K., dan Suryathi, Ni Wayan. (2018). Implementasi Kearifan Lokal Tri Hita Karana Dalam Menjaga Tri Guna Karya Kintamani Bangli. Issn: 1979-3901. DwijenAGRO Vol. 8 No. 1, Mei 2018, 8(1), 35-47.

Purana, I. M. (2016). Pelaksanaan Tri Hita Karana Dalam Kehidupan Umat Hindu. Fakultas Keguruan dan Ilmu Pendidikan. Jurnal Kajian Pendidikan Widya Accarya FKIP Universitas Dwijendra. ISSN NO. 2085-0018. Maret 2016., 2(2), 84-97.

Purnamasari, L. (2014). Pemberdayaan Perempuan Melalui Kelompok Wanita Tani (KWT) Bagi Aktualisasi Perempuan di Desa Kemanukan, Bagelen, Purworejo, Jateng. Program Studi Pendidikan Luar Sekolah Jurusan Pendidikan Luar Sekolah Fakultas Ilmu Pendidikan Universitas Negeri Yogyakarta, 5(1), 43-54. http://www.akrabjuara.com/index.php/akrabjuara/article/view/919.

Raka, A. A. G., Parwata, I. W., \& Gunawarman, A. A. G. R. (2017). Bali dalam Perspektif Budaya dan Pariwisata. Universitas Warmadewa Denpasar, 1, 119-153.

Ramantha, W. (2010). Kewirausahaan Hindu. Prosiding Seminar Kewirausahaan I, Pengembangan Entrepreneur Berdaya Saing Internasional Melalui Pemanfaatan Budaya Lokal. Malang, 18 (September), 75-81.

Riana, G. (2011). Dampak Penerapan Kultur Lokal Tri Hita Karana terhadap Orientasi Kewirausahaan dan Orientasi Pasar. Jurnal Teknik Indonestri 13 (1): 37- 44. 1 Juni 2011. ISSN 1411-2485., 8(1), 18-25. https://doi.org/10.24843/MATRIK:JMBK.

Subagia, N. K. W., Holilloh, \& Nurmalisa, Y. (2016). Persepsi Masyarakat Terhadap Konsep Tri Hita Karana Sebagai Implementasi Hukum Alam. Jurnal Kultur Demokrasi, 4(2), 103-111.

Suryathi. (2019). Kinerja Keuangan Kelompok Wanita Tani Jempiring Kabupaten Badung Berbasis Kearifan Lokal. Disertasi Universitas Udayana Denpasar, 16(3), $27-37$.

Weber, M. (2006). Etika Protestan dan Spirit Kapitalisme. Yogyakarta: Pustaka Pelajar., 6(1). https://ejournal. undiksha.ac.id/index.php/JJPE/article/download/7221/4930 
Windia, W. dan Dewi, R. K. (2007). Analisis Bisnis yang Berlandaskan Tri Hita Karana. Denpasar: Universitas

Udayana.,

$19(2)$,

198-209. https://ejournal.upi.edu/index.php/manajerial/article/view/24275.

Wulandari, N. C. (2020). Implementasi Filosofi Tri Hita Karana Dalam Pelaksanaan Kegiatan Konservasi Pada Taman Nasional Bali Barat (Tnbb), Provinsi Bali. Program Studi Agrobisnis Perikanan Jurusan Sosial Ekonomi Perikanan Dan Kelautan Fakultas Perikanan Dan Ilmu Kelautan Universitas Brawijaya Malang, July, 1-23. 